\title{
Sense of coherence and the style of interpersonal functioning and coping in adolescence
}

\begin{abstract}
BACKGROUND
Sense of coherence is widely discussed with respect to adults. The objective of this study was to find experiences (interpersonal relations and coping) forming the sense of coherence in the adolescent period. Another aim was to find a correlation between the kind of experiences resulting from the style of functioning and the kind of strategy of coping with stress.
\end{abstract}

\section{PARTICIPANTS AND PROCEDURE}

Three hundred and four subjects aged 17-19 took part in the study. The Sense of Coherence Questionnaire, the Coping with Stress Questionnaire and the Scale of Interpersonal Relations were used.

\section{RESULTS}

The analysis showed that girls are characterized by a lower level of sense of coherence. Sense of coherence is in adolescents statistically significantly associated with the follow-

\begin{abstract}
ing functional styles: self-effacing-masochistic ( $F: r=-.50$, $p<.001 / \mathrm{M}: r=-.52, p<.001)$, rebellious-distrustful $(\mathrm{F}: r=-.46$, $p<.001 / \mathrm{M}: r=-.41, p<.001)$ and emotion-focused strategy (F: $r=-.65, p<.001 / \mathrm{M}: r=-.60, p<.001)$; in girls: cooperative-overconventional $(r=.23, p<.01)$, aggressive-sadistic $(r=-.34, p<.001)$ and problem-focused strategy $(r=.40$, $p<.001)$; in boys: managerial-autocratic $(r=.47, p<.001)$. The values of the explained variance in girls and boys are comparable $(61 \%)$. In this model of explanation of the results, an aggressive-sadistic style is important for girls, but a docile-dependent style is important for boys.
\end{abstract}

\section{CONCLUSIONS}

Sense of coherence in adolescence is significantly determined by the kind of experiences connected with coping with stress and the style of interpersonal functioning.

KEY WORDS

coping; sense of coherence; adolescents; experience

organizations - The John Paul II Catholic University of Lublin, Lublin, Poland

AUthors' CONTRIBUtion - A: Study design - B: Data collection - C: Statistical analysis - D: Data interpretation .

E: Manuscript preparation · F: Literature search · G: Funds collection

CORResponding AUthor - Prof. Agnieszka Kulik, Department of Psychotherapy and Health Psychology, The John Paul II

Catholic University of Lublin, 14 Racławickie Avenue, 20-950 Lublin, Poland, e-mail: akulik@kul.pl

TO CITE THIS ARTICLE - Kulik, A. (2015). Sense of coherence and the style of interpersonal functioning and coping in

adolescence. Health Psychology Report, 3(4), 292-299. DOI: 10.5114/hpr.2015.52133

RECEIVED 01.03.2015 · REVIEWED 13.04.2015 · ACCEPTED 14.05.2015 • PUBLISHED 18.06.2015 


\section{BACKGROUND}

Sense of coherence is a person's general (global) orientation towards the world (Antonovsky, 1997). It is expressed in the conviction that: 1) stimuli coming from the environment have a structured, predictable and explicable character, which makes it possible to exercise cognitive control over one's environment; 2) a person has appropriate resources that will enable him to satisfy the requirements set by these stimuli, which makes it possible to cope individually; 3 ) the requirements are worth some effort, which motivates the person to become committed; 4) this commitment is concerned with actual, significant spheres of life. Sense of coherence consists of three dispositions: sense of comprehensibility, sense of manageability and sense of meaningfulness.

Sense of coherence performs three different functions. In adolescence a higher sense of coherence is connected with a more positive appraisal of physical health (Bergh, Baigi, Fridlund, \& Marklund, 2006; Jellesma, Rieffe, Terwogt, \& Kneepkens, 2006), lower intensity of mental health problems (Jorgensen, Frankowski, \& Carey, 1999; Kuuppelomäki \& Utriainen, 2003), better adaptation to adverse events (Surtees, Wainwright, \& Khaw, 2006; Paredes-Carbonell, Agulló-Cantos, Vera-Remartínez, \& Hernán-García, 2013), satisfaction with life (Dantasa, Motzer, \& Ciol, 2002), and academic careers (Orejudo-Hernández, Aparicio-Moreno, \& CanoEscoriaza, 2013). Among significant factors shaping sense of coherence, sexual differences are noted. In adolescent women emotional health plays a more significant role, whereas in men family stress does (Darling, McWey, Howard, \& Olmstead, 2007; Moksnes, Espnes, \& Lillefjell, 2011). A literature review on the sense of coherence and adolescence showed that "SOC is important as an individual resource for coping and will also assist in the planning of actions for the promotion of health" (Coutinho \& Heimer, 2014).

Sense of coherence especially changes in the adolescence period, when the experience of unpredictability of the world and incompatibility with it is common. According to Antonovsky, the period of early adulthood and adolescence is an important period for the development of sense of coherence because of the basic task of this period - integration of one's behavior and formation of sense of identity (Antonovsky, 2005). In this period the emotional condition, quality of life, stress connected with friendships and family stress are significant for the formation of sense of coherence (Darling et al., 2007; Moons \& Norekvål, 2006). Räty, Larsson, Söderfeldt, and Larsson (2005) found a lower level of sense of coherence in girls at the age of 13-22 than in boys, and they state that the differences especially appear in the period of 15-17 years of age. However, a 3-year longitudinal study with 16-19 year olds showed that sense of coherence is very stable at 16 and 19 years (Kröninger-Jungaberle \& Grevenstein, 2013).

Sense of coherence stems from individual experience. Life situation, especially in the family, significantly influences the level of sense of coherence (Garcia-Moya, Rivera, Moreno, Lindström, \& Jimenez-Iglesias, 2012). The formation of sense of coherence is influenced by the properties of the person, which guarantee a certain type of experiences. The character of these experiences is significant. Coherence of the experiences is connected with the ability to accurately appraise reality, maintaining balance between burdens and requirements, participation in making decisions and in being held responsible for them. Wolff and Ratner (1999) emphasize that significant life stressors decrease the lowering of the experience of the world as comprehensible, steerable and meaningful. Significant stressors in the adolescent period mainly come from the following areas: functioning in relations with other persons and coping with problems.

The style of functioning expresses the way to achieve definite tasks, which is repeated in each person in a given situation. Each person adopts a definite way to behave in a social contact, characteristic for that person. The actions that a person takes in his relations with other persons express the experience of his own person; they also define the level to which the person respects his own goals, needs, convictions, as well as those of other persons. The tendencies to adopt definite behaviors become a constant trait of personality, determining the person's willingness to perform definite functions in mutual relations and to assume definite attitudes towards others (Stanik, 1994). There may be a variety of motives to establish social relations: personal (egocentric activity) and extra-personal (pro-social activity: allocentric, sociocentric). The dominating motive to establish relations with other persons is gaining a sense of security, avoiding anxiety and maintaining a positive self-appraisal. The choice of definite styles of acting results from learning the behaviors to achieve one's own needs.

Perception of and communication with other persons (the functioning style) show a connection with stress at the level of primary appraisal (concerning the appraisal of the quality of the relations with others) and secondary appraisal (the choice of proper ways of acting). Both the intensity of social stressors and lack of them may result in a negative appraisal. Relations with other persons may be interpreted as a challenge, a loss (the person does not value them, the relations weigh him down, he is tired of them) or a threat (inability to achieve one's own goals leads to frustration, the conflict between one's own aspirations and the environment's requirements is a source of disturbance). Effectiveness of coping with stress in adolescence is influenced by complexity and diversity of the resources they have at their disposal, that is, what the adolescents use to cope with stress.
Sense of coherence in adolescence 
The greater the wealth and diversity of the accessible resources, the better the coping. The course of coping is conditioned by the properties of the situation, by the person's individual features and by their mutual interactions. Coping strategies are the same, irrespective of the age; however, differences occur as far as their preferences are concerned - along with increasing age, concentration on solving the task increases and striving after avoiding decreases (Amirkhan \& Auyeung, 2007). Also the role of gender is significant. Girls differ from boys in the choice of strategy, but these are not straight-line relationships (Hampel \& Petermann, 2006). Moreover, research conducted by Kosińska-Dec and Jelonkiewicz (1997) shows that in the group of young people at the age of 18-19 a higher sense of coherence is more frequently accompanied by concentration on the task, and less often on emotions, as well as by the ability to order the situation and to give it an emotional meaning.

\section{STUDY OBJECTIVE}

The objective of the present study is to answer the following questions: 1) What type of experiences resulting from the styles of interpersonal functioning is connected with sense of coherence in adolescence? 2) What type of experiences resulting from coping is connected with sense of coherence in adolescence? 3) What styles of interpersonal functioning and coping make it possible to forecast a high sense of coherence in adolescence? 4) What styles of interpersonal functioning determine coping in adolescence?

\section{PARTICIPANTS AND PROCEDURE}

\section{SUBJECTS AND PROCEDURE}

Three hundred and four persons were studied. The group included 120 boys and 184 girls. The subjects were aged 17-19 years; 167 subjects were aged 17 (101 girls and 66 boys), 100 subjects ( 63 girls and 37 boys) were 18; and 37 (20 girls and 17 boys) were 19 . The subjects attended post-secondary schools: 265 (164 girls and 101 boys) attended high schools, and 39 (20 girls and 19 boys) attended technical colleges.

The subjects answered the questionnaires during their lessons. The answers were anonymous.

\section{MEASURES}

Antonovsky's Sense of Coherence Questionnaire SOC-29 in the Polish version (Koniarek et al., 1993) includes 29 statements concerning various aspects of life. The subject gives answers choosing one of the possible answers from 1 (extremely negative) to
7 (extremely positive). According to an appropriate key the answers are converted to a general score and to the following scales: sense of comprehensibility, sense of manageability, sense of meaningfulness. The higher the score, the greater the intensity of sense of coherence and its components. The method has satisfactory psychometric coefficients (Kulik, 2010). The indices given in the literature range from .68 to .92 . The internal consistency measured by Cronbach's $\alpha$ in our own study of a group of young people had a value of .69 to .87 (Kulik, 2010). These data allow application of a tool that is designed for measuring sense of coherence in adults and teenagers, like in the research by Hagquist and Andrich (2004).

The Coping with Stress Questionnaire (Streßverarbeitungsfragebogen) by Janke, Erdmann, Boucsein (Polish version: Kwestionariusz Sposobów Opracowania Stresu - KSOS) includes 114 statements by means of which the subject indicates how often s/he behaves in a definite way in a stress situation (Januszewska, 2005). The subject takes a stance on each proposition, choosing one of the possible answers: never, rarely, sometimes, often, always. Definite values from 0 to 4 are ascribed to each of the answers. The score is the sum of raw points obtained in each of the scales. The higher the score, the greater is the intensity of the way of coping with stress. Particular statements are assigned, according to an appropriate key, to one of the 19 scales. The scales make up four strategies: the problem-focused, emotion-focused, syntoxic, and escape strategy. The tool has statistical value compared with the basic version (Januszewska, 2005).

Stanik's Scale of Interpersonal Relations (SUI) consists of 70 statements, on which the subject takes a stance by choosing one of the three possible answers: "yes" / "?" / "no" (Stanik, 1994). The statements have been assigned to twelve scales. Eight scales express the interpersonal style of functioning (managerial-autocratic, responsible-hypernormal, cooperative-overconventional, docile-dependent, selfeffacing-masochistic, rebellious-distrustful), aggressive-sadistic, competitive-narcissistic); four additional ones are used for differential diagnosis (Stanik, 1994). Raw scores in the scales fall in the range 0-12 except Scale VI, in which the scores are in the range $0-10$. The higher the score, the greater is the intensity of the style. Reliability indices measured by means of correlation between two measures range from .69 to .89 (Różańska-Kowal, 2000; Stanik, 1994).

\section{RESULTS}

\section{SENSE OF COHERENCE IN ADOLESCENCE}

The analyses were made separately for girls and boys on the basis of premises about differentiated intensity of sense of coherence depending on the gender. 
For assessing the intensity of the variables the mean and the standard deviation were used. Significance of the differences between the means scored by girls and boys was measured by means of Student's $t$-test. Results statistically describing sense of coherence in adolescence are shown in Table 1.

On the basis of Table 1 statistically significant differences can be found between girls and boys in the intensity of sense of coherence $(t=-3.64, p<.001)$, sense of comprehensibility $(t=-3.62, p<.001)$, and sense of manageability $(t=-3.98, p<.001)$.

\section{SENSE OF COHERENCE AND STYLES OF INTERPERSONAL FUNCTIONING AND COPING STRATEGIES}

Analysis of the data was performed to try to answer the question concerning 1) the connection between interpersonal functioning styles and sense of coherence in girls and boys, and 2) the connection between coping and sense of coherence. Pearson's $r$ was used to measure the connection between the exogenous variables and the endogenous variable (Table 2).

On the basis of the data from Table 2 it may be stated that in girls sense of coherence is statistically significantly correlated with the following styles of interpersonal functioning: cooperative-overconventional $(r=.23, p<.01)$, self-effacing-masochistic $(r=-.50$, $p<.001)$, rebellious-distrustful $(r=-.46, p<.001)$, aggressive-sadistic $(r=-.34, p<.001)$. In boys sense of coherence is significantly correlated with the following styles: managerial-autocratic $(r=.47, p<.001)$, self-effacing-masochistic $(r=-.52, p<.001)$ and rebellious-distrustful $(r=-.41, p<.001)$.

Table 2 also shows that the correlation of sense of coherence and coping strategies in girls is significant with respect to the problem-focused $(r=.40, p<.001)$ and emotion-focused $(r=-.65, p<.001)$ coping strategies, whereas in boys it is significant only in the relation with the emotion-focused strategy $(r=-.60$, $p<.001)$.

\section{DETERMINANTS OF SENSE OF COHERENCE}

An analysis was performed to determine which variables condition sense of coherence in girls and boys (step 1). In the next part the analysis tackled the question of which styles of interpersonal functioning condition particular coping strategies that play a significant role in explaining sense of coherence (step 2).

The following variables were introduced into the model of sense of coherence: problem-focused strategy, emotion-focused strategy, syntoxic strategy, escape strategy, managerial-autocratic style, respon-

Table 1

Descriptive statistics of variables measured in adolescence divided with respect to gender

\begin{tabular}{lrrrrc}
\hline \multicolumn{1}{c}{ Variables } & \multicolumn{2}{c}{$\begin{array}{c}\text { Girls } \\
n=184\end{array}$} & \multicolumn{2}{c}{$\begin{array}{c}\text { Boys } \\
n=120\end{array}$} & $\begin{array}{c}\text { Significance of } \\
\text { differences }\end{array}$ \\
\cline { 2 - 6 } & $M$ & $S D$ & $M$ & $S D$ & $p$ \\
\hline sense of coherence & 117.12 & 22.67 & 126.60 & 21.53 & $<.001$ \\
sense of comprehensibility & 38.78 & 8.35 & 42.33 & 8.40 & $<.001$ \\
sense of manageability & 42.06 & 9.49 & 46.41 & 9.02 & $<.001$ \\
sense of meaningfulness & 36.27 & 9.32 & 37.77 & 8.48 & n.s. \\
\hline
\end{tabular}

Table 2

Relations (Pearson's r) between the exogenous variables and sense of coherence in girls $(n=184)$ and boys $(n=120)$

\begin{tabular}{|c|c|c|c|c|c|}
\hline \multirow[t]{2}{*}{ Variables } & \multicolumn{2}{|c|}{$\begin{array}{c}\text { Sense } \\
\text { of coherence }\end{array}$} & \multirow[t]{2}{*}{ Variables } & \multicolumn{2}{|c|}{$\begin{array}{c}\text { Sense } \\
\text { of coherence }\end{array}$} \\
\hline & $\mathrm{F}$ & M & & $\mathrm{F}$ & M \\
\hline managerial-autocratic style & & $.47^{\star \star *}$ & aggressive-sadistic style & $-.34^{\star \star \star *}$ & \\
\hline responsive-hypernormal style & & & competitive-narcissistic style & & \\
\hline $\begin{array}{l}\text { cooperative-overconventional } \\
\text { style }\end{array}$ & $.23^{* *}$ & & problem-focused strategy & $.40^{* \star *}$ & \\
\hline docile-dependent style & & & emotion-focused strategy & $-.65^{\star \star \star}$ & $-.60^{* * *}$ \\
\hline self-effacing-masochistic style & $-.50^{* * \star}$ & $-.52^{\star \star \star *}$ & syntoxic strategy & & \\
\hline rebellious-distrustful style & $-.46^{* \star *}$ & $-.41^{\star \star \star}$ & escape strategy & & \\
\hline
\end{tabular}


sive-hypernormal style, cooperative overconventional style, docile-dependent style, self-effacing-masochistic style, rebellious-distrustful style, aggressive-sadistic style, and competitive-narcissistic style. The determination coefficient and the role of the exogenous variables explaining the endogenous variable were determined on the basis of regression analysis with the help of the stepwise method. Using the beta values from the regression analysis a model was created of mutual explanation, separately for girls and boys. The models are presented in Table 3 and Table 4.

Step 1 . The values of the explained variance in girls and boys are comparable. In about $61 \%$ the results in sense of coherence are explained by the following variables: emotion-focused strategy, problem-focused strategy, managerial-autocratic style, self-effacingmasochistic style and rebellious-distrustful style.

Step 2. In girls the styles of interpersonal functioning explain the problem-focused strategy in $21 \%$.
For the problem-focused strategy the following styles proved significant: self-effacing-masochistic, cooperative-overconventional, managerial-autocratic and aggressive-sadistic.

In girls and boys the styles of interpersonal functioning determine a similar value of the variability of results - about $28 \%$ and $30 \%$, respectively. For the emotional strategy in girls the self-effacing-masochistic and aggressive-sadistic styles were important. The model for boys contains different characteristics: the managerial-autocratic, self-effacing-masochistic and docile-dependent styles proved significant.

\section{DISCUSSION}

The aim of the present study was to show what kind of experiences in interpersonal relations and in coping with problems shape sense of coherence in ado-

Table 3

The model of sense of coherence for girls in the light of regression analysis by the stepwise method

\begin{tabular}{|c|c|c|c|c|c|c|c|c|c|}
\hline Model & $B$ & $\beta$ & $t$ & $p$ & $R^{2}$ & $F$ & $p$ & $\begin{array}{c}R^{2} \\
\text { change } \\
\text { value }\end{array}$ & $p$ \\
\hline \multicolumn{10}{|l|}{ Step 1 - sense of coherence } \\
\hline const. & 137.75 & & 19.83 & $<.001$ & & & & \multirow{2}{*}{.43} & \multirow{2}{*}{$<.001$} \\
\hline emotion-focused strategy & -2.89 & -.43 & -7.95 & $<.001$ & & & & & \\
\hline problem-focused strategy & 1.72 & .21 & 4.32 & $<.001$ & & & & .09 & $<.001$ \\
\hline rebellious-distrustful style & -2.98 & -.29 & -5.54 & $<.001$ & .62 & 56.89 & $<.001$ & .05 & $<.001$ \\
\hline $\begin{array}{l}\text { self-effacing-masochistic } \\
\text { style }\end{array}$ & -1.44 & -.18 & -3.30 & .001 & & & & .03 & $<.001$ \\
\hline $\begin{array}{l}\text { managerial-autocratic } \\
\text { style }\end{array}$ & 1.07 & .13 & 2.57 & .011 & & & & .01 & .011 \\
\hline
\end{tabular}

Step 2 - coping strategies significant for sense of coherence

a) emotion-focused strategy

\begin{tabular}{|c|c|c|c|c|c|c|c|c|c|}
\hline const. & 9.04 & & 20.05 & $<.001$ & & & & & \\
\hline $\begin{array}{l}\text { self-effacing-masochistic } \\
\text { style }\end{array}$ & 0.56 & .46 & 7.31 & $<.001$ & .28 & 35.16 & $<.001$ & .19 & $<.001$ \\
\hline aggressive-sadistic style & 0.37 & .30 & 4.67 & $<.001$ & & & & .09 & $<.001$ \\
\hline
\end{tabular}

Step 2 - coping strategies significant for sense of coherence

b) problem-focused strategy

\begin{tabular}{|c|c|c|c|c|c|c|c|c|c|}
\hline const. & 11.24 & & 13.40 & $<.001$ & & & & & \\
\hline $\begin{array}{l}\text { self-effacing-masochistic } \\
\text { style }\end{array}$ & -0.23 & -.22 & -3.27 & .001 & & & & .06 & .001 \\
\hline $\begin{array}{l}\text { cooperative-overconven- } \\
\text { tional style }\end{array}$ & 0.25 & .23 & 3.11 & .002 & .21 & 11.68 & $<.001$ & .07 & $<.001$ \\
\hline $\begin{array}{l}\text { managerial-autocratic } \\
\text { style }\end{array}$ & 0.27 & .27 & 3.80 & $<.001$ & & & & .05 & .002 \\
\hline aggressive-sadistic style & -0.21 & -.20 & -2.71 & .007 & & & & .03 & .007 \\
\hline
\end{tabular}


Table 4

The model of sense of coherence for boys in the light of regression analysis by the stepwise method

\begin{tabular}{|c|c|c|c|c|c|c|c|c|c|}
\hline Model & $B$ & $\beta$ & $t$ & $p$ & $R^{2}$ & $F$ & $p$ & $\begin{array}{c}R^{2} \\
\text { change } \\
\text { value }\end{array}$ & $p$ \\
\hline \multicolumn{10}{|l|}{ Step 1 - sense of coherence } \\
\hline const. & 129.83 & & 21.24 & $<.001$ & & & & \multirow{2}{*}{.36} & \multirow{2}{*}{$<.001$} \\
\hline emotion-focused strategy & -2.59 & -.46 & -6.48 & $<.001$ & & & & & \\
\hline problem-focused strategy & 2.01 & .30 & 4.80 & $<.001$ & & & & .11 & $<.001$ \\
\hline rebellious-distrustful style & -2.62 & -.26 & -4.23 & $<.001$ & .61 & 35.79 & .001 & .09 & $<.001$ \\
\hline $\begin{array}{l}\text { self-effacing-masochistic } \\
\text { style }\end{array}$ & -1.40 & -.18 & -2.60 & .011 & & & & .03 & .003 \\
\hline $\begin{array}{l}\text { managerial-autocratic } \\
\text { style }\end{array}$ & 1.24 & .16 & 2.43 & .017 & & & & .02 & .017 \\
\hline
\end{tabular}

Step 2 - coping strategies significant for sense of coherence

a) emotion-focused strategy

\begin{tabular}{|c|c|c|c|c|c|c|c|c|c|}
\hline const. & 6.25 & & 5.07 & $<.001$ & & & & & \\
\hline $\begin{array}{l}\text { self-effacing-masochistic } \\
\text { style }\end{array}$ & 0.51 & .37 & 4.38 & $<.001$ & & & & .23 & $<.001$ \\
\hline $\begin{array}{l}\text { managerial-autocratic } \\
\text { style }\end{array}$ & 0.29 & .20 & 2.50 & .014 & .30 & 16.48 & $<.001$ & .04 & .016 \\
\hline docile-dependent style & -0.26 & -.19 & -2.25 & .027 & & & & .03 & .027 \\
\hline
\end{tabular}

Step 2 - coping strategies significant for sense of coherence

b) problem-focused strategy

\begin{tabular}{|c|c|c|c|c|c|c|c|c|c|}
\hline const. & 8.18 & & 7.55 & $<.001$ & & & & 07 & 002 \\
\hline docile-dependent style & 0.34 & .28 & 3.19 & .002 & .11 & 6.83 & .002 & & \\
\hline $\begin{array}{l}\text { managerial-autocratic } \\
\text { style }\end{array}$ & 0.21 & .18 & 2.10 & .038 & & & & .03 & .038 \\
\hline
\end{tabular}

lescence. Another issue was to find a correlation between the kind of experiences resulting from the style of functioning and the kind of the strategy of coping with stress. The analyses were made separately for girls and boys due to the differences in the intensity of sense of coherence that are connected with gender.

The study has shown - as it could be supposed on the basis of earlier reports (Räty et al., 2005) - that the intensity of sense of coherence and its components is different in girls and boys. Only in the scale of sense of meaningfulness are the results similar. Girls encounter more difficulties in understanding the reality in which they are functioning, and in activating the resources to meet the requirements they face.

Sense of coherence in girls is higher, the higher are the intensity of positive attitudes to another person, the trend towards harmony in interpersonal relations, concentration on solving difficult situations and using cooperation with others in this process. The greater the hostility and tendencies to self-sacrifice in social relations as well as concentration on one's own emotions in difficult situations, the lower is the sense of coherence. These data are basically similar to the report by Darling et al. (2007). They emphasize the role of the emotional condition and the quality of close relations in shaping sense of coherence in girls in the period of adolescence. Similarly, Jelonkiewicz and Kosińska-Dec (2004) stress that while no difference is found with respect to gender in defining the number of stressing events, it is noted that stress is more strongly experienced by girls. Girls perceive themselves as part of a network of interpersonal relations and pay more attention to the quality of these relations than boys do (Brannon, 2002).

In boys sense of coherence is higher, the more intense is the leadership activity and tendency to achieve aims together. The more experiences expressing submission, helplessness, alienation and coping with stress by concentrating on oneself there are, the lower the sense of coherence is.
Sense of coherence in adolescence 
The presented data suggest that direct determinants of sense of coherence both in girls and in boys are similar. Intensification of sense of coherence in young people is favored by experiences in problem solving and establishing interpersonal relations marked by cooperation in trying to achieve common aims originating from experiencing oneself and others in the category of "I am OK, you are OK". Such experiences allow young people to recognize social requirements, principles and rules operating in the environment, and in this way to shape the reality. Experiences of effectiveness in problem solving build the sense of one's own competence and the sense of causation, make one realize the wealth of the resources one has, and strengthen the confidence in oneself and in others, making one's personal involvement meaningful. At the same time the style of functioning expressing leadership tendencies in the context of cooperation and affiliation favors shaping positive experiences in coping with problems.

Concentration on emotions and the style of interpersonal relations characterized by hostile docility weaken sense of coherence. At the same time, in shaping emotional strategies a difference connected with gender is noted. In girls this process is favored by hostility and frustration resulting from negative experiences with other persons epitomized in the rule "I am not OK, you are not OK". In boys the emotional strategy is determined by the experience of docility, passivity, and self-effacement connected with experiencing one's own weakness and contempt shown by the social environment, according to the principle "I am not OK, you are OK".

The presented results are similar to the analyses performed by Oleszkowicz (2006). In the context of adolescent rebellion she draws the reader's attention to the fact that reactive negativism is a reaction to interpersonal disappointment, whereas proactive negativism is an expression of involvement in achieving definite ideals. Both these kinds of negativism perform an adaptive function in the adolescence period.

\section{LIMITATIONS}

The research was done in the 17-19 years age group, with the oldest subjects constituting the smallest group. The aspect of discomfort connected with the adolescent crisis was not monitored in the group, which could have influenced the distinctiveness of the presented experiences.

Another important task of the adolescent period is formation of identity. Also this aspect was not taken into consideration in the research process. In further research it is worth paying attention to specifying more precisely the kind of experiences (outside the area of interpersonal relations and coping) adolescents have as well as to their situation in life.
This research received no specific grant support from any funding agency in the public, commercial, or notfor-profit sectors.

\section{References}

Amirkhan, J., \& Auyeung, B. (2007). Coping with stress across the lifespan: Absolute vs. relative changes in strategy. Journal of Applied Developmental Psychology, 28, 298-317.

Antonovsky, A. (1997). Poczucie koherencji jako determinanta zdrowia [The Sense of Coherence as a Determinant of Health]. In: I. Heszen-Niejodek \& H. Sęk (eds.), Psychologia zdrowia [Health Psychology] (pp. 206-231). Warszawa: PWN.

Antonovsky, A. (2005). Rozwiktanie tajemnicy zdrowia. Jak radzić sobie ze stresem i nie zachorować [Unraveling the mystery of health]. Warszawa: Instytut Psychiatrii i Neurologii.

Bergh, H., Baigi, A., Fridlund, B., \& Marklund, B. (2006). Life events, social support and sense of coherence among frequent attenders in primary health care. Public Health, 120, 229-236.

Brannon, L. (2002). Psychologia rodzaju [Gender. Psychological Perspectives]. Gdańsk: GWP.

Coutinho, V. M., \& Heimer M. V. (2014). Sense of coherence and adolescence: an integrative review of the literature. Ciência \& Saúde Coletiva, 19, 819-827.

Dantasa, R. A. S., Motzer, S. A., \& Ciol, M. A. (2002). The relationship between quality of life, sense of coherence and self-esteem in persons after coronary artery bypass graft surgery. International Journal of Nursing Studies, 39, 745-755.

Darling, C. A., McWey, L. M., Howard, S. N., \& Olmstead, S. B. (2007). College student stress: the influence of interpersonal relationships on sense of coherence. Stress and Health, 23, 215-229.

Garcia-Moya, I., Rivera, F., Moreno, C., Lindström, B., \& Jimenez-Iglesias, A. (2012). Analysis of the importance of family in the development of sense of coherence during adolescence. Scandinavian Journal of Public Health, 40, 333-339.

Hagquist, C., \& Andrich, D. (2004). Is the Sense of Coherence-instrument applicable on adolescents? A latent trait analysis using Rasch-modelling. Personality and Individual Differences, 36, 955-968.

Hampel, P., \& Petermann, F. (2006). Perceived stress, coping, and adjustment in adolescents. Journal of Adolescent Health, 38, 409-415.

Januszewska, E. (2005). Kwestionariusz Radzenia sobie ze Stresem (KRS). Wartość diagnostyczna i wyniki badań młodzieży [The Coping with Stress Questionnaire: Diagnostic Value and Results from Studies in Adolescents]. In: M. Oleś (ed.), Wybrane zagadnienia z psychologii klinicznej i osobowości. Metody diagnostyczne w badaniach 
dzieci i mtodzieży [Issues of clinical psychology and personality. Diagnostic methods in studies of children and adolescents] (pp. 91-123). Lublin: TN KUL.

Jellesma, F. C., Rieffe, C., Terwogt, M. M., \& Kneepkens, C. M. F. (2006). Somatic complaints and health care use in children: Mood, emotion awareness and sense of coherence. Social Science \& Medicine, 63, 2640-2648.

Jelonkiewicz, I., \& Kosińska-Dec, K. (2004). Spostrzegane zasoby a doświadczanie stresu rodzinnego i szkolnego wśród młodzieży [Perceived resources and experience of family and school stress among young people]. In: K. Kosińska-Dec \& L. Szewczyk (eds.), Rozwój - zdrowie - choroba. Aktualne problemy psychosomatyki [Development-health-disease. Current problems of psychosomatics] (pp. 71-90). Warszawa: BEL Studio Sp. z o.o.

Jorgensen, R. S., Frankowski, J. J., \& Carey, M. P. (1999). Sense of coherence, negative life events and appraisal of physical health among university students. Personality and Individual Differences, 27, 1079-1089.

Koniarek, J., Dudek, B., \& Makowska, Z. (1993). Kwestionariusz Orientacji Życiowej. Adaptacja The Sense of Coherence Questionnaire (SOC) A. Antonovsky'ego [Orientation to Life Questionnaire. Adaptation of The Sense of Coherence Questionnaire (SOC) A. Antonovsky]. Przegląd Psychologiczny, 36, 491-502.

Kosińska-Dec, K., \& Jelonkiewicz, I. (1997). Poczucie koherencji a style radzenia sobie - zmiany w czasie [Sense of coherence and coping styles changes over time]. In: L. Szewczyk (ed.), Radzenie sobie i pomoc innym w zdrowiu i chorobie [Coping and helping others in health and disease] (pp. 3943). Lublin: Akademia Medyczna.

Kröninger-Jungaberle, H., \& Grevenstein, D. (2013). Development of salutogenetic factors in mental health - Antonovsky's sense of coherence and Bandura's self-efficacy related to Derogatis' symptom check list (SCL-90-R). Health and Quality of Life Outcomes, 11, 80-89.

Kulik, A. (2010). Zmęczenie przewlekte u nastolatków. Charakterystyka psychologiczna [Chronic fatigue in teenagers. Psychological characteristics]. Lublin: Wydawnictwo KUL.

Kuuppelomäki, M., \& Utriainen, P. (2003). A 3 year follow-up study of health care students' sense of coherence and related smoking, drinking and physical exercise factors. International Journal of Nursing Studies, 40, 383-388.

Moksnes, U. K., Espnes, G. A., \& Lillefjell, M. (2011). Sense of coherence and emotional health in adolescents. Journal of Adolescence, 35, 433-441.

Moons, P., \& Norekvål, T. M. (2006). Is sense of coherence a pathway for improving the quality of life of patients who grow up with chronic diseases?
A hypothesis. European Journal of Cardiovascular Nursing, 5, 16-20.

Oleszkowicz, A. (2006). Bunt mtodzieńczy. Uwarunkowania. Formy. Skutki [The rebelliousness of youth. Determinants. Forms. Consequences]. Warszawa: Wydawnictwo Naukowe Scholar.

Orejudo-Hernández, S., Aparicio-Moreno, L., \& Cano-Escoriaza, J. (2013). Personal competencies of Spanish students pursuing different academic careers. Contributions and reflections from positive psychology. Journal of Behavior, Health \& Social Issues, 5, 63-78.

Paredes-Carbonell, J. J., Agulló-Cantos, J. M., VeraRemartínez, E. J., \& Hernán-García, M. (2013). Sense of coherence and health assets in a youth center for minors. Journal of Spanish Prison Health, 15, 87-97.

Räty, L. K. A., Larsson, G., Söderfeldt, B. A., \& Larsson, B. M. W. (2005). Psychosocial aspects of health in adolescence: the influence of gender, and general self-concept. Journal of Adolescent Health, 36, 530.e21-530.e28.

Różańska-Kowal, J. (2000). Psychologiczna diagnoza niedostosowania społecznego młodzieży w świetle badań testem SUI (wyniki badań i normalizacja testu) [The psychological diagnosis of young people's social maladaptation in the light of the results of a Sui test]. In: J. M. Stanik (ed.), Psychologia. Badania i aplikacje. Trudności i zaburzenia w społecznym funkcjonowaniu człowieka (tom 3) [Psychology: Research and Applications. Difficulties and perturbations in man's social functioning] (pp. 78-93). Katowice: Wydawnictwo Uniwersytetu Śląskiego.

Stanik, J. M. (1994). Skala Ustosunkowań Interpersonalnych (SUI) [The Scale of Interpersonal Relationships]. Kielce: Wydawnictwo Szumacher.

Surtees, P. G., Wainwright, N. W. J., \& Khaw, K.-T. (2006). Resilience, misfortune, and mortality: evidence that sense of coherence is a marker of social stress adaptive capacity. Journal of Psychosomatic Research, 61, 221-227.

Wolff, A. C., \& Ratner, P. A. (1999). Stress, social support, and sense of coherence. Western Journal of Nursing Research, 21, 182-197.
Sense of coherence in adolescence 